\title{
X-Ray Absorption Characterization of Diesel Exhaust Particulates
}

\author{
A.J. Nelson, J.L Ferreira, J.G. Reynolds, J.W. Roos
}

This article was submitted to

Materials Research Society Meeting, Boston, MA, November 29 December 3, 1999

\section{November 18, 1999}

U.S. Department of Energy

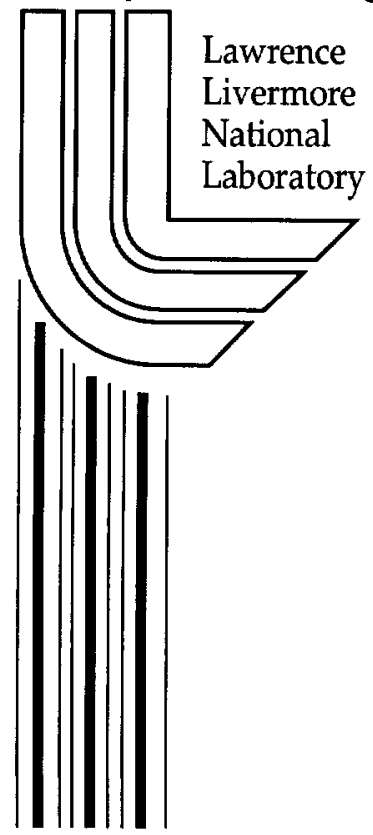




\section{DISCLAIMER}

This document was prepared as an account of work sponsored by an agency of the United States Government. Neither the United States Government nor the University of California nor any of their employees, makes any warranty, express or implied, or assumes any legal liability or responsibility for the accuracy, completeness, or usefulness of any information, apparatus, product, or process disclosed, or represents that its use would not infringe privately owned rights. Reference herein to any specific commercial product, process, or service by trade name, trademark, manufacturer, or otherwise, does not necessarily constitute or imply its endorsement, recommendation, or favoring by the United States Government or the University of California. The views and opinions of authors expressed herein do not necessarily state or reflect those of the United States Government or the University of California, and shall not be used for advertising or product endorsement purposes.

This is a preprint of a paper intended for publication in a journal or proceedings. Since changes may be made before publication, this preprint is made available with the understanding that it will not be cited or reproduced without the permission of the author.

This report has been reproduced directly from the best available copy.

Available electronically at http://www.doe.gov/bridge

Available for a processing fee to U.S. Department of Energy and its contractors in paper from

U.S. Department of Energy

Office of Scientific and Technical Information

$$
\text { P.O. Box } 62
$$

Oak Ridge, TN 37831-0062

Telephone: (865) 576-8401

Facsimile: (865) 576-5728

E-mail: reports@adonis.osti.gov

Available for the sale to the public from

U.S. Department of Commerce

National Technical Information Service

5285 Port Royal Road

Springfield, VA 22161

Telephone: (800) 553-6847

Facsimile: (703) 605-6900

E-mail: orders@ntis.fedworld.gov

Online ordering: http://www.ntis.gov/ordering.htm

OR

Lawrence Livermore National Laboratory

Technical Information Department's Digital Library

http://www.llnl.gov/tid/Library.html 


\title{
X-RAY ABSORPTION CHARACTERIZATION OF DIESEL EXHAUST PARTICULATES
}

\author{
A. J. NELSON", J. L. FERREIRA*, J. G. REYNOLDS* and J. W. ROOS** \\ "Lawrence Livermore National Laboratory, Livermore, CA 94550 \\ **Ethyl Corporation, Richmond, VA 23217
}

\begin{abstract}
We have characterized particulates from a 199311.1 Detroit Diesel Series 60 engine with electronic unit injectors operated using fuels with and without methylcyclopentadienyl manganese tricarbonyl (MMT) and overbased calcium sulfonate added. X-ray photoabsorption (XAS) spectroscopy was used to characterize the diesel particulates. Results reveal a mixture of primarily $\mathrm{Mn}$-phosphate with some $\mathrm{Mn}$-oxide, and Ca-sulfate on the surface of the filtered particulates from the diesel engine.
\end{abstract}

\section{INTRODUCTION}

Methylcyclopentadienyl manganese tricarbonyl (MMT) is an effective means of increasing octane quality of gasoline. [1] Comprehensive automotive testing also shows that vehicles using MMT (0.03125 gram manganese per gallon) in gasoline had $6 \%$ lower $\mathrm{CO}$ emissions and $20 \%$ lower $\mathrm{NO}_{\mathrm{x}}$ emissions than automobiles operating on base gasoline. [2] In another application, it is proposed that MMT with overbased calcium alkylbenzene sulfonate (OCABS) be employed as a fuel additive package to reduce diesel smoke and particulate emissions. [3] OCABS are also used to impart detergency in engine oils and fuel combustion catalysts. $[4,5]$

Identification of the manganese and calcium species formed by the decomposition of MMT and OCABS in diesel engines is of practical importance and of environmental interest. These species end up either on surfaces in the exhaust system of an automobile or are emitted into the atmosphere.

This paper reports on an investigation to determine the surface composition of particulates emitted from vehicles operating on fuel containing various concentrations of MMT and calcium sulfonate using $X$-ray absorption spectroscopy (XAS).

\section{EXPERIMENTAL}

Particulate samples from diesel engine test runs using fuels with and without methylcyclopentadienyl manganese tricarbonyl (MMT) and overbased calcium alkylbenzene sulfonate added were characterized. The fuels used were Colonial diesel (389 ppm S) and Howell diesel (460 ppm S). The particulate samples were collected on filter paper. The test runs are summarized in Table I. It should be noted that engine operation time for Run 1716 had a duration five times that of the other test runs resulting in $5 \mathrm{X}$ exposure of the filter. 
Model compounds were analyzed by XAS and XPS to provide a basis for quantitative analysis of the unknown particulates. The model compounds $\mathrm{CaO}, \mathrm{CaCO}_{3}, \mathrm{CaSO}_{4}, \mathrm{Ca}_{2} \mathrm{P}_{2} \mathrm{O}_{7}$, $\mathrm{Ca}\left(\mathrm{H}_{2} \mathrm{PO}_{4}\right)_{2}, \mathrm{Ca}\left(\mathrm{NO}_{3}\right)_{2}, \mathrm{CaCl}_{2}, \mathrm{MnO}, \mathrm{Mn}_{2} \mathrm{O}_{3}, \mathrm{Mn}_{3} \mathrm{O}_{4}, \mathrm{MnO}_{2}, \mathrm{Mn}\left(\mathrm{OCH}_{3}\right)_{2}, \mathrm{MnPO}_{4}$, $\mathrm{Mn}_{5}\left(\mathrm{PO}_{4}\right)_{2}\left[\mathrm{PO}_{3}(\mathrm{OH})\right]_{2} \bullet 4 \mathrm{H}_{2} \mathrm{O}$ (Mn-Phos) (Alfa Aesar), $\mathrm{Mn}\left(\mathrm{CH}_{3} \mathrm{COCH}=\mathrm{COCH}_{3}\right)_{3}\left(\mathrm{Mn}(\mathrm{acac})_{3}\right)$, $\mathrm{MnS}$ (Aldrich) and $\mathrm{MnSO}_{4} \cdot \mathrm{H}_{2} \mathrm{O}$ (Mallinckrodt) were used as received. The powder samples were pressed into indium foil and attached to the sample holder, which was then introduced into the ultra-high vacuum (UHV) chamber for analysis. Similarly, small pieces of the particulate on filter samples were cut and mounted with indium foil on the sample holder prior to their introduction into the analysis chamber.

Table I. Summary of Parameters for Diesel Particulate Test Run Samples

\begin{tabular}{|c|c|c|c|c|}
\hline Run Number & $\begin{array}{c}\text { Mn } \\
\text { (mg Mn/liter) }\end{array}$ & $\begin{array}{c}\text { Ca } \\
\text { (mg Ca/liter) }\end{array}$ & Fuel & $\begin{array}{c}\text { Engine } \\
\text { Operation Time } \\
\text { (min.) }\end{array}$ \\
\hline \hline 1716 & 3 & 18 & Colonial & 100 \\
\hline 1599 & 50 & 0 & Howell & 20 \\
\hline 1632 & 0 & 50 & Howell & 20 \\
\hline 1605 & 8 & 0 & Howell & 20 \\
\hline 1616 & 0 & 8 & Howell & 20 \\
\hline 1658 & 6 & 36 & Howell & 20 \\
\hline 1591 & 18 & 0 & Howell & 20 \\
\hline 1626 & 0 & 18 & Howell & 20 \\
\hline
\end{tabular}

Manganese $2 p$ and calcium $2 p$ core-level XAS were performed on these particulates and the series of $\mathrm{Mn}$ and Ca compound standards. This technique probes empty or unfilled $3 \mathrm{~d}$ electronic states of manganese and provides information on the local chemical environment. For $2 p$ X-ray absorption, the dipole allowed transitions are $2 p \rightarrow 3 d$ and $2 p \rightarrow 4 s$, with transitions to the $3 \mathrm{~d}$ states dominating. The observed behavior has been interpreted as the combination of crystal field effects with splittings due to multipole $2 p-3 d$ and $3 d-3 d$ interactions. Crystal field effects, measured by the cubic crystal field parameter, are equal for both the initial and final states. Also, the $2 \mathrm{p}$ core hole spin-orbit coupling splits the absorption spectrum into a $2 \mathrm{p}_{3 / 2}\left(\mathrm{~L}_{3}\right)$ and a $2 p_{1 / 2}\left(L_{2}\right)$ part. In addition, it has been observed that the branching ratio of the $L_{3}$ edge intensity to the total line strength depends on the oxidation state of the $\mathrm{Mn}$ and $\mathrm{Ca}$. Specifically for $\mathrm{Mn}$, this branching ratio decreases in the order $\mathrm{Mn}(\mathrm{II}) \rightarrow \mathrm{Mn}(\mathrm{III}) \rightarrow \mathrm{Mn}(\mathrm{IV})$. [6,7] This analysis was performed at the 8-2 beam line at the Stanford Synchrotron Radiation Laboratory (SSRL) by scanning the photon energy of the incoming monochromatic synchrotron radiation through the Mn 2p and Ca 2p core-level edge (L-edge) while monitoring the total electron yield. The spectra were calibrated arbitrarily with $640 \mathrm{eV}$ for the absorption maximum in the Mn model compounds and $\sim 347 \mathrm{eV}$ for the $\mathrm{Ca}$ model compounds. [8]

\section{RESULTS}

\section{$X A S$ - Model Compounds}

Figure 1 presents the Mn 2p core level XAS of the Mn model compounds. Analysis of these series of model compounds provides standard Mn L-edge spectra of several formal valences, specifically, $\mathrm{Mn}(\mathrm{II})$ in $\mathrm{MnSO}_{4}, \mathrm{MnO}$ and $\mathrm{Mn}$-Phos, $\mathrm{Mn}$ (III) in $\mathrm{MnPO}_{4}$, and a mixture of $\mathrm{Mn}(\mathrm{II})$ and $\mathrm{Mn}(\mathrm{III})$ in $\mathrm{Mn}_{3} \mathrm{O}_{4}$. All spectra show two absorption regions, the $\mathrm{Mn} 2 \mathrm{p}_{3 / 2}\left(\mathrm{~L}_{3}\right)$ at $\sim 640 \mathrm{eV}$ and $\mathrm{Mn} 2 \mathrm{p}_{1 / 2}\left(\mathrm{~L}_{2}\right)$ at $\sim 650 \mathrm{eV}$. Characteristic features of the absorption regions depends 
upon the ligand environments and the oxidation states. For example, $\mathrm{Mn}_{3} \mathrm{O}_{4}$ shows a sharp and broad $L_{3}$ region and a very broad $L_{2}$ region reflecting the oxide environment and the mixture of $\mathrm{Mn}(\mathrm{II})$ and $\mathrm{Mn}$ (III) oxidation states, while $\mathrm{Mn}$-Phos and $\mathrm{MnSO}_{4}$ show a relatively sharp $\mathrm{L}_{3}$ region reflecting the single oxidation state $\mathrm{Mn}(\mathrm{II})$. Also note the differences in the energy

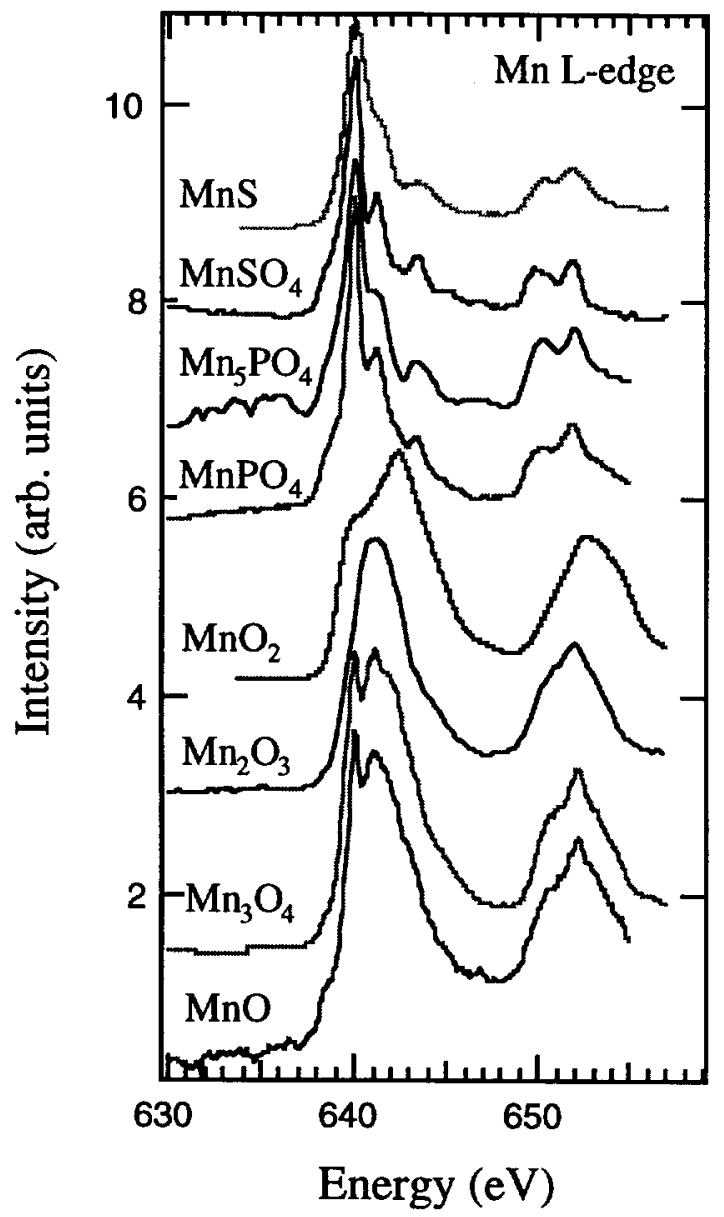

Figure 1. Mn L-edge photoabsorption spectra of model compounds.

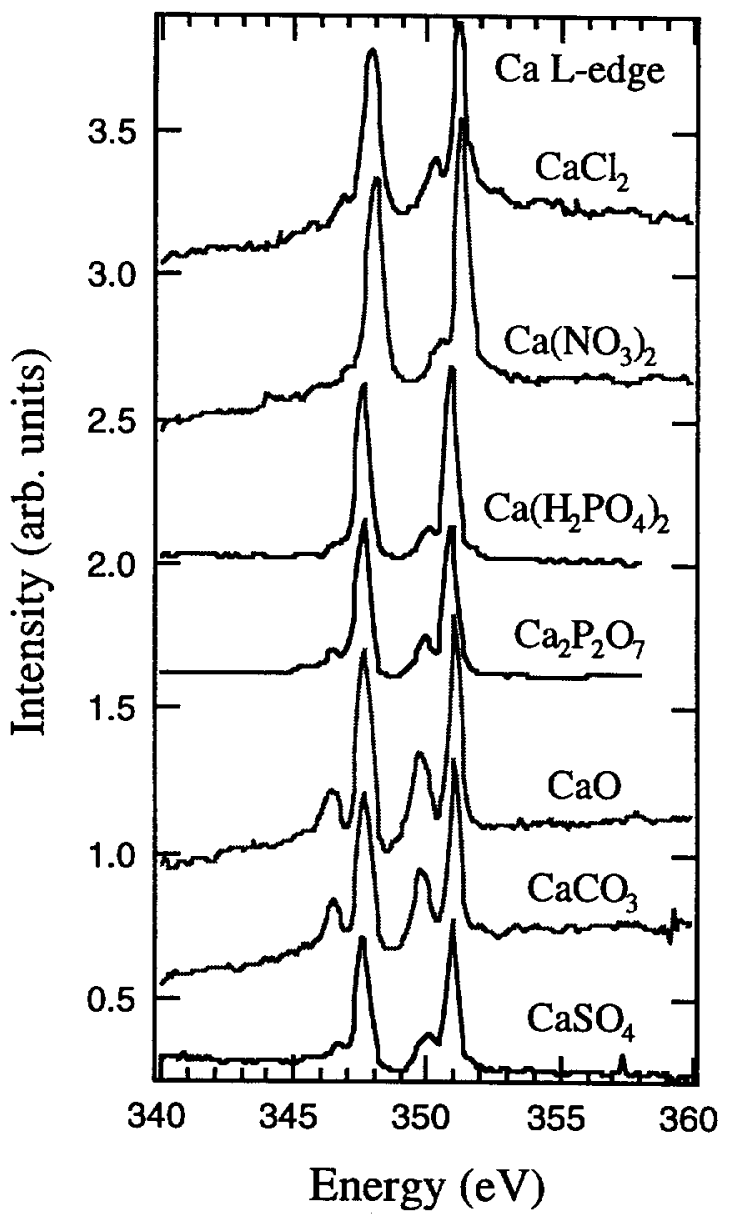

Figure 2. Ca L-edge photoabsorption spectra of model compounds.

separation between the $L_{3}$ and $L_{2}$ peaks and their relative intensities as well as the shoulder on the low energy side of the $\mathrm{L}_{3}$ peak for the phosphate and sulfate. Table II summarizes the pertinent Mn L-edge spectral characteristics.

Table II. Summary of the Mn L-edge Spectral Features for Mn Model Compounds.

\begin{tabular}{|c|c|c|c|c|}
\hline Compound & $\begin{array}{c}\text { Formal Mn } \\
\text { Valency }\end{array}$ & $\begin{array}{c}\Delta \mathrm{E}\left(\mathrm{L}_{3}-\mathrm{L}_{2}\right) \\
(\mathrm{eV})\end{array}$ & $\begin{array}{c}\mathrm{L}_{3} \text { Linewidth } \\
\text { FWHM }(\mathrm{eV})\end{array}$ & $\begin{array}{c}\text { Branching Ratio } \\
\left(\mathrm{L}_{3}\right) /\left(\mathrm{L}_{3}+\mathrm{L}_{2}\right)\end{array}$ \\
\hline \hline $\mathrm{MnO}$ & II & 12.0 & 4.2 & 0.60 \\
\hline $\mathrm{Mn}_{3} \mathrm{O}_{4}$ & II, III & 12.0 & 4.2 & 0.62 \\
\hline $\mathrm{Mn}_{2} \mathrm{O}_{3}$ & III & 11.0 & 3.8 & 0.62 \\
\hline $\mathrm{MnO}_{2}$ & IV & 10.2 & 5.3 & 0.61 \\
\hline $\mathrm{MnPO}_{4}$ & III & 11.8 & 1.0 & 0.78 \\
\hline Hureaulite $^{\mathrm{a}}$ & II & 11.8 & 1.3 & 0.78 \\
\hline $\mathrm{MnSO}_{4}$ & II & 11.8 & 1.1 & 0.82 \\
\hline $\mathrm{MnS}$ & II & 11.8 & 1.6 & 0.82 \\
\hline
\end{tabular}

a) $\mathrm{Mn}_{5}\left(\mathrm{PO}_{4}\right)_{2}\left[\mathrm{PO}_{3}(\mathrm{OH})\right]_{2} \bullet 4 \mathrm{H}_{2} \mathrm{O}$. 
Figure 2 presents the Ca $2 \mathrm{p}$ core level XAS of the Ca model compounds. All spectra show two areas of absorption, $\mathrm{Ca} 2 \mathrm{p}_{3 / 2}\left(\mathrm{~L}_{3}\right)$ at $\sim 348 \mathrm{eV}$ and $\mathrm{Ca} 2 \mathrm{p}_{1 / 2}\left(\mathrm{~L}_{2}\right)$ at $\sim 351 \mathrm{eV}$. Also, smaller associated absorptions are seen as either shoulders or resolved satellite peaks for both $L_{3}$ and $L_{2}$ in all spectra. Quantitative determination of the model compound $\mathrm{Ca}$ species relies on energy separations of the small satellite peak and the associated main peak of the Ca L-edge spectra as are summarized in Table III. Since Ca only occurs as $\mathrm{Ca}$ (II), subtle differences in the peak shapes, $\Delta \mathrm{E}\left(\mathrm{L}_{3 \mathrm{a}}-\mathrm{L}_{3 \mathrm{~b}}\right)$, linewidths and the branching ratio will be utilized to determine $\mathrm{Ca}$ speciation in the diesel particulates.

Table III. Summary of the Ca L-edge Spectral Features for Ca Model Compounds.

\begin{tabular}{|c|c|c|c|c|}
\hline Compound & $\begin{array}{c}\Delta \mathrm{E}\left(\mathrm{L}_{3}-\mathrm{L}_{2}\right) \\
(\mathrm{eV})\end{array}$ & $\begin{array}{c}\Delta \mathrm{E}\left(\mathrm{L}_{3 \mathrm{a}}-\mathrm{L}_{3 \mathrm{~b}}\right) \\
(\mathrm{eV})\end{array}$ & $\begin{array}{c}\mathrm{L}_{3} \text { Linewidth } \\
\text { FWHM }(\mathrm{eV})\end{array}$ & $\begin{array}{c}\text { Branching Ratio } \\
\left.\left(\mathrm{L}_{3}\right) / \mathrm{I}_{3}+\mathrm{L}_{2}\right)\end{array}$ \\
\hline \hline $\mathrm{CaSO}_{4}$ & 3.4 & 0.8 & 0.6 & 0.46 \\
\hline $\mathrm{CaO}$ & 3.4 & 1.2 & 0.7 & 0.45 \\
\hline $\mathrm{CaCO}_{3}$ & 3.4 & 1.1 & 0.7 & 0.46 \\
\hline $\mathrm{Ca}_{2} \mathrm{P}_{2} \mathrm{O}_{3}$ & 3.2 & 1.1 & 0.7 & 0.50 \\
\hline $\mathrm{Ca}\left(\mathrm{H}_{2} \mathrm{PO}_{4}\right)_{2}$ & 3.2 & 0.8 & 0.7 & 0.48 \\
\hline $\mathrm{Ca}\left(\mathrm{NO}_{3}\right)_{2}$ & 3.2 & 0.8 & 0.8 & 0.43 \\
\hline $\mathrm{CaCl}_{2}$ & 3.3 & 1.0 & 0.8 & 0.46 \\
\hline
\end{tabular}

\section{XAS Analysis - diesel particulates}

The Mn XAS spectra for the diesel particulate samples are presented in Figure 3. Table IV summarizes the spectral characteristics. From visual comparison, these spectra best match the $\mathrm{Mn}$ L-edge spectrum for $\mathrm{Mn}_{2} \mathrm{O}_{3}$. The $\mathrm{L}_{3}$ linewidth suggests a mixture of species, most likely containing oxide. The $\mathrm{L}_{3}-\mathrm{L}_{2}$ energy separation suggests pure oxides or a mixture of oxides and other species such as phosphate and sulfate. The branching ratios suggest a mixture of phosphate and/or sulfate with oxides. 


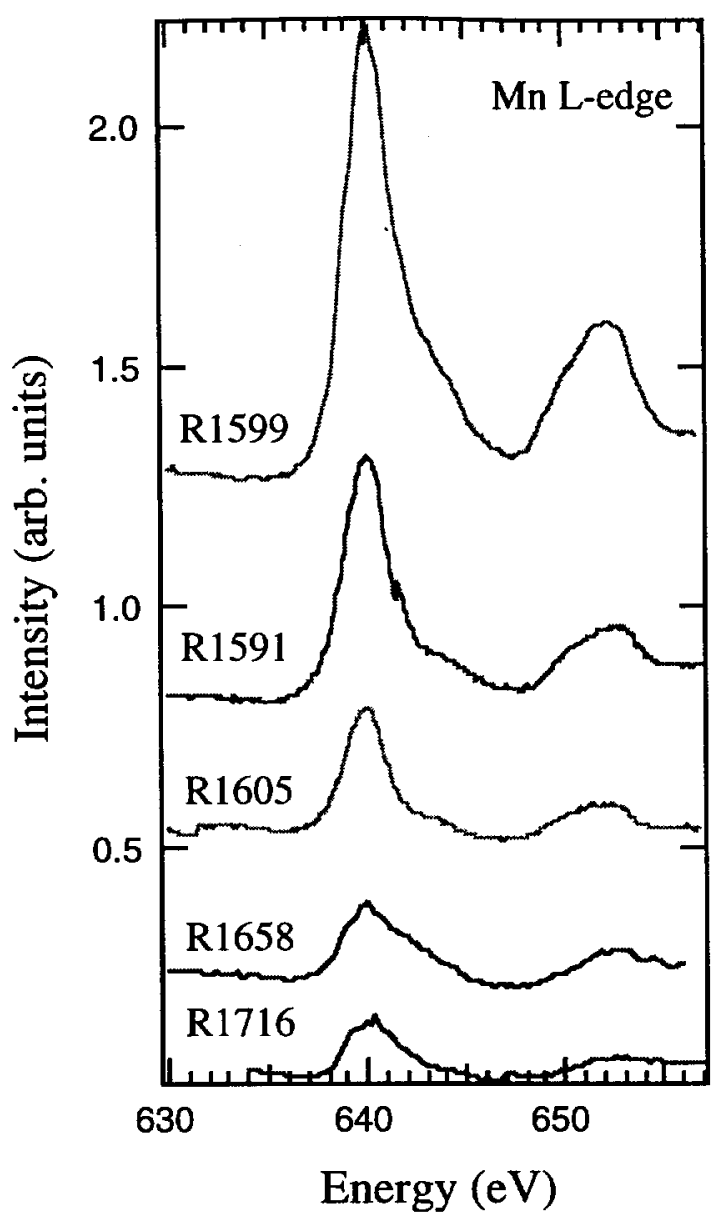

Figure 3. Mn L-edge photoabsorption spectra of diesel particulates.

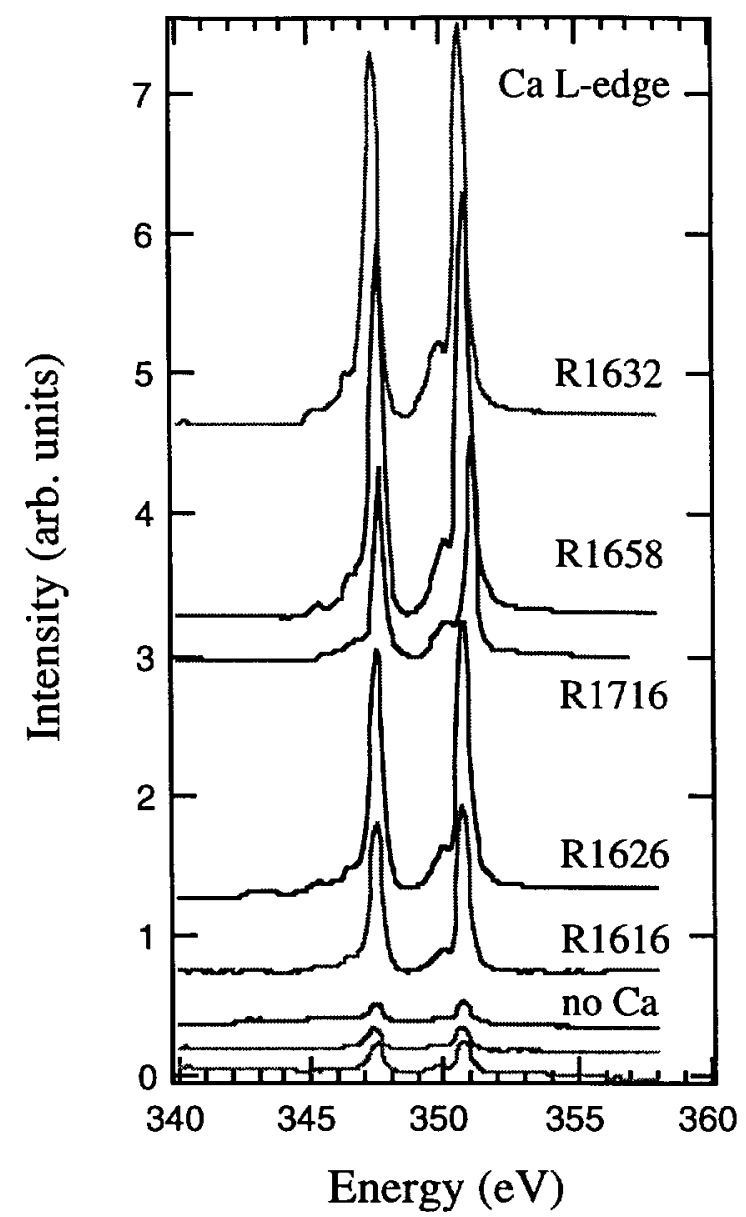

Figure 4. Ca L-edge photoabsorption spectra of diesel particulates.

Table IV. Summary of the Mn L-edge Spectral Features for Diesel Particulates

\begin{tabular}{|c|c|c|c|}
\hline Sample & $\begin{array}{c}\Delta \mathrm{E}\left(\mathrm{L}_{3}-\mathrm{L}_{2}\right) \\
(\mathrm{eV})\end{array}$ & $\begin{array}{c}\mathrm{L}_{3} \text { Linewidth } \\
\text { FWHM }(\mathrm{eV})\end{array}$ & $\begin{array}{c}\text { Branching Ratio } \\
\left(\mathrm{L}_{3}\right) /\left(\mathrm{L}_{3}+\mathrm{L}_{2}\right)\end{array}$ \\
\hline Run 1716 & 12.0 & 3.2 & 0.73 \\
\hline Run $1599^{\dagger}$ & 12.0 & 3.2 & 0.77 \\
\hline Run $1632^{\ddagger}$ & - & - & - \\
\hline Run $1605^{\dagger}$ & 12.0 & 2.7 & 0.79 \\
\hline Run $1616^{\ddagger}$ & - & - & 0.67 \\
\hline Run 1658 & 12.0 & 3.2 & 0.79 \\
\hline Run $1591^{\dagger}$ & 12.0 & 2.8 & - \\
\hline Run $1626^{\ddagger}$ & - & - & - \\
\hline
\end{tabular}

${ }^{\dagger}$ no $\mathrm{Ca}$ added to fuel, ${ }^{\ddagger}$ no $\mathrm{Mn}$ added to fuel

The Ca XAS spectra for the diesel particulate samples are presented in Figure 4. Table V summarizes the spectral characteristics. Visual comparison of the $\mathrm{Ca}_{3}$ spectral features for the diesel particulates with the $\mathrm{Ca} \mathrm{L}_{3}$ spectral features for the $\mathrm{Ca}$ model compounds would seem to indicate that the $\mathrm{Ca}$ speciation has several possibilities and that the species may be different for some of the samples. The $\mathrm{L}_{3}$ linewidth suggests in all cases $\mathrm{CaSO}_{4}$. The $\mathrm{L}_{3}-\mathrm{L}_{2}$ energy separation suggests phosphate and nitrate (chloride is most likely not occurring because of the lack of a chloride source). The $\mathrm{L}_{3 \mathrm{a}}-\mathrm{L}_{3 b}$ satellite separation suggests sulfate, phosphate, and nitrate. The branching ratio suggests phosphate and sulfate. 
Table V. Summary of the Ca L-edge Spectral Features for the Diesel Particulates

\begin{tabular}{|c|c|c|c|c|}
\hline Sample & $\begin{array}{c}\Delta \mathrm{E}\left(\mathrm{L}_{3}-\mathrm{L}_{2}\right) \\
(\mathrm{eV})\end{array}$ & $\begin{array}{c}\Delta \mathrm{E}\left(\mathrm{L}_{3 \mathrm{a}}-\mathrm{L}_{3 \mathrm{~b}}\right) \\
(\mathrm{eV})\end{array}$ & $\begin{array}{l}\mathrm{L}_{3} \text { Linewidth } \\
\text { FWHM (eV) }\end{array}$ & $\begin{array}{l}\text { Branching Ratio } \\
\mathrm{I}\left(\mathrm{L}_{3}\right) / \mathrm{I}\left(\mathrm{L}_{3}+\mathrm{L}_{2}\right)\end{array}$ \\
\hline Run 1716 & 3.5 & 1.0 & 0.5 & 0.47 \\
\hline Run $1599^{\dagger}$ & - & - & - & - \\
\hline Run $1632^{\ddagger}$ & 3.3 & 1.0 & 0.6 & 0.49 \\
\hline Run $1605^{\dagger}$ & - & - & - & - \\
\hline Run $1616^{\ddagger}$ & 3.2 & 0.9 & 0.6 & 0.47 \\
\hline Run 1658 & 3.2 & 1.0 & 0.6 & 0.48 \\
\hline Run $1591^{\dagger}$ & - & - & - & - \\
\hline Run $1626^{\ddagger}$ & 3.3 & 0.9 & 0.6 & 0.47 \\
\hline
\end{tabular}

${ }^{\dagger}$ no $\mathrm{Ca}$ added to fuel, ${ }^{\ddagger}$ no $\mathrm{Mn}$ added to fuel

\section{CONCLUSIONS}

We have applied XAS to identify Mn and Ca species in exhaust particulates from a diesel engine operated using fuel with MMT and overbased calcium alkylbenzene sulfonate. These compounds are reported to improve combustion characteristics leading to reduced diesel smoke and particulate emissions.

We have compared the energy separation of the XAS $L_{3}$ and $L_{2}$ edges, the $L_{3}$ linewidth, and the branching ratio of these diesel samples with the spectral characteristics of the $\mathrm{Mn}$ and $\mathrm{Ca}$ model compounds to determine the surface composition of the samples. Results for the diesel particulate samples indicate that the $\mathrm{Mn}$ is present as a mixture of phosphate and/or sulfate with oxides and that the $\mathrm{Ca}$ is primarily present as $\mathrm{CaSO}_{4}$, consistent with the higher operating temperatures. A high sulfur content fuel and diesel operating conditions would probably yield primarily sulfates. However, Ethyl simulations indicate that $\mathrm{MnSO}_{4}$ is not stable at higher temperatures.

\section{Acknowledgments}

The XAS work was performed at the Stanford Synchrotron Radiation Laboratory, which is supported by the U.S. Department of Energy, Office of Basic Energy Sciences, under Contract No. DE-AC03-76SF00515.

\section{REFERENCES}

1. J. E. Faggan, J. D. Bailie, E. A. Desmond and D. L. Lenane, SAE Paper 750925 (1975), Warrenville, PA: Society for Automobile Engineering.

2. D. P. Hollrah and A. M. Burns, Oil \& Gas Journal, March 11, 1991, pp. 86-90.

3. G.R. Wallace, Hydrocarbonaceous Fuel Composition and Additives Thereof, US Pat 5944858.

4. G.G. Pritzker, Natl. Petroleum News 37, 793 (1945).

5. J.F. Marsh, Colloidal lubricant additives, Chem. Ind. (London, 1987) p. 470.

6. S.P. Cramer, F.M.F. deGroot, Y. Ma, C.T. Chen, F. Sette, C.A. Kipke, D.M. Eichhorn, M.K. Chan, W.H. Armstrong, E. Libby, G. Christou, S. Brooker, V. McKee, O.C. Mullins and J.C. Fuggle, J. Am. Chem. Soc. 113, 7937 (1991).

7. M.M. Grush, J. Chen, T.L. Stremmler, S.J. George, C.Y. Ralston, R.T. Stibrany, A. Gelasco, G. Christou, S.M. Gorun, J.E. Penner-Hahn and S.P. Cramer, J. Am. Chem. Soc. 118, 65 (1996). 8. Zhanfeng Yin, M. Kasrai, G.M. Bancroft, K. Fyfe, M.L. Colaianni and K.H. Tan, Wear 202, 192 (1997).

This work was performed under the auspices of the U.S. Department of Energy by the University of California, Lawrence Livermore National Laboratory under Contract No. W-7405-Eng-48. 